\title{
UPAYA GURU MATEMATIKA SMA KOTA BALIKPAPAN DALAM PENINGKATAN MUTU KINERJA SEBAGAI PENDIDIK
}

\author{
Antonia Lusia Ina Kewa ${ }^{1}$, Mochammad Alipatan ${ }^{2}$, Nur Ismiyati ${ }^{3}$ \\ Universitas Balikpapan ${ }^{1}$, Universitas Balikpapan ${ }^{2}$, Universitas Balikpapan ${ }^{3}$ \\ pos-el: antoniaina17@gmail.com ${ }^{1}$, alipatan9@yahoo.com², nurismiyati@uniba-bpn.ac.id ${ }^{3}$
}

\begin{abstract}
ABSTRAK
Guru sebagai tenaga profesional mempunyai fungsi, peran, dan kedudukan yang sangat penting dalam mencapai visi pendidikan yaitu menciptakan insan Indonesia cerdas dan kompetitif. Penelitian ini menggunakan pendekatan kualitatif metode deskriptif dengan analisis kasus. Berdasarkan temuan hasil penelitian, bahwa upaya yang dilakukan guru matematika dalam peningkatan mutu kinerja sebagai pendidik adalah (1) mengembangkan kurikulum dengan cara membuat silabus dengan berdasarkan pada kurikulum, membuat RPP sesuai dengan silabus yang mencakup mata pelajaran, materi pokok, alokasi waktu . (2) Penilaian dan evaluasi dengan cara menyusun alat penilaian yang sesuai dengan tujuan pembelajaran dengan berbagai jenis seperti yang tertulis dalam RPP. (3) Bersikap inklusif, bertindak obyektif serta tidak diskriminatif dengan cara memperlakukan peserta didik secara adil, dan menjaga hubungan baik dengan teman sejawat. (4) Menunjukkan pribadi yang dewasa dan teladan dengan cara bertingkah laku sopan dalam berbicara berpenampilan serta bersikap dewasa dalam menerima masukan dari peserta didik. (5) Mengembangkan keprofesian melalui tindakan reflektif dengan cara selalu mengevaluasi diri, mengikuti pelatihan, seminar, dan kegiatan MGMP.
\end{abstract}

Kata kunci : upaya guru, kinerja guru, kompetensi guru

\section{ABSTRACT}

Teachers as professionals have a very important function, role and position in achieving the vision of education, namely to create intelligent and competitive Indonesians. This study is a qualitative approach, descriptive method with case analysis. Based on the findings of the research results, the efforts made by mathematics teachers in improving the quality of performance as educators are (1) developing a curriculum by making a syllabus based on the curriculum, making lesson plans according to the syllabus which includes subjects, subject matter, time allocation. (2) Assessment and evaluation by preparing assessment tools in accordance with various types of learning objectives as written in the lesson plan. (3) Being inclusive, acting objectively and not discriminating by treating students fairly, and maintaining good relations with colleagues. (4) Showing an adult and exemplary person by behaving politely in speaking, appearance and being mature in receiving input from students. (5) Developing professionalism through reflective action by always evaluating yourself, attending training, seminars and MGMP activities.

Keywords: teacher effort, teacher performance, teacher competence

\section{PENDAHULUAN}

Untuk menghasilkan guru dan siswa yang berprestasi dan berkualitas, dibutuhkan suatu kinerja guru yang kompeten dibidangnya serta terampil dalam menguasai beberapa media pembelajaran . Standar kinerja merupakan patokan dalam mengadakan pertanggungjawaban terhadap segala hal yang telah dikerjakan. Standar kinerja guru berhubungan langsung dengan kualitas guru dalam menjalankan tugasnya seperti: bekerja sama dengan siswa secara individual, persiapan dan perencanaan pembelajaran, pendayagunaan media pembelajaran, melibatkan siswa salam berbagai pengalaman belajar, dan kepemimpinan yang aktif dari guru.

Menurut Peraturan Menteri Negara Pendayagunaan Aparatur Negara dan Reformasi Birokrasi Nomor 16 Tahun 2009, Penilaian Kinerja Guru adalah 
penilaian dari tiap butir kegiatan tugas utama guru dalam rangka pembinaan karier, kepangkatan, dan jabatannya. Selanjutnya Mulyasa (2013) menyatakan penilaian kinerja guru dapat diartikan sebagai suatu upaya untuk memperoleh gambaran tentang pengetahuan, keterampilan, nilai dan sikap guru dalam melaksanakan tugas dan fungsinya, yang ditunjukkan dalam perbuatan, penampilan, dan prestasi kerjanya.

Berdasarkan observasi pendahuluan dan wawancara langsung dengan mantan kepala sekolah SMA Negeri 8 Balikpapan yakni Bapak Agus Ikhsan, M.Pd pada bulan Januari, diperoleh data bahwa kinerja guru matematika di sekolah ini memiliki kinerja yang cukup baik. Sekolah ini mempunyai kedisiplinan tinggi yang ditunjukkan kepada seluruh warga sekolah. Guru dalam menjalankan tugasnya dituntut memiliki 4 kompetensi yakni kompetensi pedagogik, kompetensi profesional, kompetensi kepribadian dan kompetensi sosial.

Kompetensi kepribadian merupakan kemampuan personal yang mencerminkan kepribadian yang mantap, stabil, dewasa, arif, dan berwibawa, menjadi teladan bagi peserta didik, dan berakhlak mulia. Kompetensi ini menjadi bagian dari soft skills yang harus dimiliki oleh seorang guru agar mampu menjadi teladan bagi semua peserta didiknya. Secara rinci setiap elemen kepribadian tersebut dapat dijabarkan menjadi sub kompetensi dan indikator esensial sebagai berikut (Sumardi, 2016, p.15).

Kompetensi pedagogik merupakan kemampuan yang berkenaan dengan pemahaman peserta didik dan pengelolaan proses pembelajaran yang mendidik dan dialogis. Secara substantif kompetensi ini mencakup kemampuan pemahaman terhadap peserta didik, perancangan dan pelaksanaan pembelajaran, evaluasi hasil belajar, dan pengembangan peserta didik untuk mengaktualisasikan berbagai potensi yang dimilikinya (Sumardi, 2016, p.16).
Kompetensi profesional merupakan kemampuan yang berkenaan dengan penguasaan materi pembelajaran bidang studi secara luas dan mendalam yang mencakup penguasaan substansi isi materi kurikulum mata pelajaran di sekolah dan substansi isi materi kurikulum mata pelajaran di sekolah dan substansi keilmuan yang menaungi materi kurikulum tersebut, serta menambah wawasan keilmuan sebagai guru.

Kompetensi sosial berkenaan dengan kemampuan pendidik sebagai bagian dari masyarakat untuk berkomunikasi dan bergaul secara efektif dengan peserta didik, sesama pendidik, tenaga kependidikan, orang tua/wali peserta didik, dan masyarakat sekitar. Kompetensi ini memiliki sub kompetensi dengan indikator esensial (Sumardi, 2016, p.18) yaitu mampu berkomunikasi dan bergaul secara efektif dengan peserta didik. Sub kompetensi ini memiliki indikator esensial: berkomunikasi secara efektif dengan peserta didik, mampu berkomunikasi dan bergaul secara efektif dengan sesama pendidik dan tenaga kependidikan serta mampu berkomunikasi dan bergaul secara efektif dengan orang tua/wali peserta didik dan masyarakat sekitar.

Menurut Peraturan Menteri Negara Pendayagunaan Aparatur Negara dan Reformasi Birokrasi Nomor 16 Tahun 2009, Penilaian Kinerja Guru adalah penilaian dari tiap butir kegiatan tugas utama guru dalam rangka pembinaan karir, kepangkatan, dan jabatannya. Pelaksanaan tugas utama guru tidak dapat dipisahkan dari kemampuan seorang guru dalam penguasaan pengetahuan, penerapan pengetahuan dan keterampilan, sebagai kompetensi yang dibutuhkan sesuai amanat Peraturan Menteri Pendidikan Nasional Nomor 16 Tahun 2007 tentang Standar Kualifikasi Akademik dan Kompetensi Guru.

Penguasaan kompetensi dan penerapan pengetahuan serta keterampilan guru, sangat menentukan tercapainya kualitas 
proses pembelajaran atau pembimbingan peserta didik, dan pelaksanaan tugas tambahan yang relevan bagi sekolah/madrasah, khususnya bagi guru dengan tugas tambahan tersebut. Sistem PK GURU adalah sistem penilaian yang dirancang untuk mengidentifikasi kemampuan guru dalam melaksanakan tugasnya melalui pengukuran penguasaan kompetensi yang ditunjukkan dalam unjuk kerjanya.

Pedoman Pelaksanaan Penilaian Kinerja Guru antara lain berdasarkan ketentuan dimana penilaian kinerja guru harus dilaksanakan sesuai dengan prosedur dan mengacu pada peraturan yang berlaku. Selanjutnya berdasarkan kinerja dimana aspek yang dinilai dalam penilaian kinerja guru adalah kinerja yang dapat diamati dan dipantau sesuai dengan tugas guru sehari-hari dalam melaksanakan kegiatan pembelajaran, pembimbingan, dan/atau tugas tambahan yang relevan dengan fungsi sekolah/madrasah. Selain itu berdasarkan dokumen dimana penilai, guru yang dinilai, dan unsur lain yang terlibat dalam proses penilaian kinerja guru harus memahami semua dokumen yang terkait dengan sistem penilaian kinerja guru, terutama yang berkaitan dengan pernyataan kompetensi dan indikator kinerjanya secara utuh, sehingga penilai, guru dan unsur lain yang terlibat dalam proses penilaian kinerja guru mengetahui dan memahami tentang aspek yang dinilai serta dasar dan kriteria yang digunakan dalam penilaian.

Penilaian kinerja guru dilaksanakan secara konsisten dan teratur setiap tahun yang diawali dengan evaluasi diri, dengan memperhatikan hal-hal berikut antara lain; obyektif, adil, akuntabel, bermanfaat, transparan, berorientasi pada tujuan, berorientasi pada proses, berkelanjutan, dan rahasia.

Dengan demikian, tujuan uji kompetensi adalah menilai dan menetapkan apakah guru sudah kompeten atau belum dilihat dari hasil tersebut sangat berbeda dengan penilaian yang dilakukan kepala sekolah untuk itu perlu pembinaan penguasaan kompetensi dan penilaian kinerja guru secara obyektif.

Penelitian ini bertujuan untuk mengetahui dan mendeskripsikan kinerja guru serta upaya yang dilakukan guru matematika dalam mengembangkan kurikulum, penilaian dan evaluasi, bersikap inklusif, bertindak obyektif, serta tidak diskriminatif, menunjukkan sikap pribadi yang dewasa dan teladan, serta mengembangkan keprofesian melalui tindakan reflektif.

\section{METODE PENELITIAN}

Ditinjau dari jenis data yang digunakan pada penelitian ini adalah pendekatan kualitatif. Teknik pengumpulan data kualitatif Observasi, wawancara dan dokumentasi. Adapun yang dimaksud dengan penelitian kualitatif adalah suatu penelitian yang ditujukan untuk mendeskripsikan dan menganalisis fenomena, peristiwa, aktivitas sosial, sikap, kepercayaan, persepsi, pemikiran orang secara individual maupun kelompok (Sukmadinata, 2015, p. 60). Kemudian, dalam ruang lingkup keilmuan, Nelson (Hamzah, 2019) berpendapat bahwa penelitian kualitatif merupakan bidang antar-disiplin, lintas-disiplin dan terkadang kontra disiplin. Penelitian kualitatif menyentuh humaniora, ilmu sosial dan ilmu fisik. Ia memiliki fokus perhatian dengan beragam paradigma.

Penelitian kualitatif ini dipilih karena gejala-gejala, informasi-informasi atau keterangan-keterangan dari hasil pengamatan selama berprosesnya penelitian mengenai "Upaya Guru Matematika SMA Kota Balikpapan dalam Peningkatan Mutu Kinerja sebagai Pendidik" akan tepat bila diungkap dalam bentuk kalimat, yang berasal dari naskah wawancara, catatan, lapangan, foto atau dokumen sehingga peneliti menganalisis.

Dengan pendekatan kualitatif, metode deskriptif, analisis kasus yang dilakukan 
secara komprehensif, sehingga proses pengumpulan dan penyajian data hasil penelitian tidak hanya bertumpu pada halhal yang mengemuka saja, tetapi juga dengan berupaya melihat faktor-faktor yang melatar belakangi Upaya Guru Matematika SMA Kota Balikpapan dalam Peningkatan Mutu Kinerja Sebagai Pendidik.

\section{HASIL DAN PEMBAHASAN}

Berdasar temuan hasil penelitian, upaya yang dilakukan guru matematika di SMA Negeri 8 Balikpapan untuk meningkatkan mutu kinerja sebagai pendidik dalam mengembangkan kurikulum yakni dengan menyusun silabus, merancang rencana pembelajaran, memilih materi pembelajaran dengan memperhatikan tujuan pembelajaran serta memilih materi pembelajaran yang sesuai dengan tujuan pembelajaran serta sesuai dengan konteks kehidupan sehari-hari peserta didik.

Guru dapat menyusun silabus sesuai dengan kurikulum, RPP dikembangkan guru menyesuaikan dengan apa yang dinyatakan dalam silabus, dengan kondisi di satuan pendidikan yang mencakup mata pelajaran, materi pokok, alokasi waktu selanjutnya merancang RPP sesuai dengan standar isi, tujuan pembelajaran , metode pembelajaran , media dalam alat sumber belajar, langkahlangkah kegiatan pembelajaran dan penilaian yang dibuat bersama dalam forum MGMP matematika SMA.

Kurikulum adalah seperangkat rencana dan pengaturan mengenai tujuan, isi dan bahan pelajaran serta cara yang digunakan sebagai pedoman penyelenggaraan kegiatan pembelajaran untuk mencapai tujuan pendidikan tertentu ( UU nomor 20 tahun 2003; PP nomor 32 tahun 2013). Dari amanat undang-undang tersebut dapat dilaksanakan ditingkat satuan pendidikan dengan maksud agar memungkinkan penyesuaian program pendidikan dengan kondisi dan kekhasan potensi yang ada di daerah serta peserta didik. Dengan demikian, kurikulum adalah rancangan untuk konten pendidikan yang harus dimiliki oleh seluruh peserta didik setelah menyelesaikan pendidikannya di satu satuan atau jenjang pendidikan tertentu. Kurikulum sebagai proses merupakan totalitas pengalaman belajar peserta didik.

Upaya guru matematika di SMA Negeri 8 dalam meningkatkan mutu kinerja sebagai tenaga pendidik antara lain dengan menyusun alat penilaian yang sesuai dengan tujuan pembelajaran dengan berbagai jenis penilaian seperti yang tertulis dalam RPP.

Teknik dan instrumen yang digunakan untuk penilaian kompetensi sikap, pengetahuan dan keterampilan sebagai berikut: pertama, pendidik melakukan penilaian kompetensi sikap melalui observasi penilaian diri, penilaian teman sejawat, oleh peserta didik dan jurnal. Kedua, pendidik menilai kompetensi pengetahuan melalui tes tertulis, tes lisan dan penugasan. ketiga, pendidik menilai kompetensi keterampilan melalui penilaian kinerja yang menuntut peserta didik mendemonstrasikan suatu kompetensi tertentu dengan menggunakan tes praktik, proyek, dan penilaian portofolio, namun ada beberapa guru tidak menganalisis hasil penilaian untuk mengidentifikasi topik/kompetensi dasar yang sulit.

Upaya Kinerja Guru dalam Meningkatkan Mutu Kinerja sebagai pendidik dalam bersikap inklusif, bertindak obyektif, serta tidak diskriminatif adalah dengan memperlakukan semua peserta didik secara adil, menjaga hubungan baik dan peduli dengan teman sejawat serta sering berinteraksi dengan peserta didik dan tidak membatasi perhatiannya hanya pada kelompok tertentu.

Menurut Undang-Undang Nomor 14 tahun 2005 tentang Guru dan Dosen, yang di dalamnya menegaskan bahwa kompetensi sosial adalah kemampuan guru untuk berkomunikasi dan 
berinteraksi secara efektif dan efisien dengan peserta didik, sesama guru, orang tua/wali peserta didik, dan masyarakat sekitar. Selanjutnya Casmudi \& Alipatan (2019: 73) kemampuan guru untuk berkomunikasi dengan peserta didik secara efektif dan empati adalah suatu keharusan selama proses layanan pendidikan atau pembelajaran disekolah atau di luar sekolah.

Pandangan yang sama dalam PP 32 tahun 2013 tentang standar nasional pendidikan pasal 28 menjelaskan bahwa kompetensi sosial merupakan kemampuan guru sebagai bagian dari masyarakat untuk berkomunikasi, bergaul secara efektif, dengan peserta didik, sesama pendidik, tenaga pendidik, orang tua dan masyarakat sekitar.

Berdasarkan temuan peneliti dan dukungan teori maka disimpulkan bahwa upaya guru matematika dalam meningkatkan kinerja guru yakni dengan memperlakukan semua peserta didik secara adil, menjaga hubungan baik dan peduli dengan teman sejawat serta sering berinteraksi dengan peserta didik dan tidak membatasi perhatiannya hanya pada kelompok tertentu.

Upaya guru dalam meningkatkan mutu kinerja guru sebagai tenaga pendidik dalam menunjukkan pribadi yang dewasa dan teladan yaitu dengan bertingkah laku sopan dalam berbicara, berpenampilan dan berbuat baik terhadap semua peserta didik, orang tua, dan teman sejawat serta bersikap dewasa dalam menerima masukan dari peserta didik dan memberikan kesempatan kepada peserta didik untuk berpartisipasi dalam proses pembelajaran. Guru yang dewasa ditunjukkan dengan bersikap sabar, mengontrol emosi , tidak cepat marah dan bisa mengondisikan diri pada situasi tertentu. Setiap guru memiliki sikap kepribadian yang berbeda-beda, dan mempunyai karakter yang berbeda-beda setelah peneliti bertanya sikap dewasa pada peserta didik.
Menurut Moh \& Nurfuadi (2009, p. 15) mengatakan bahwa " Seorang guru harus mempunyai kepribadian sehat yang akan mendorongnya mencapai puncak prestasi. Kepribadian yang sehat diartikan kepribadian yang secara fisik dan psikis terbebas dari penyakit tetapi bisa juga diartikan sebagai individu yang secara psikis selalu berusaha menjadi sehat.

Upaya guru dalam meningkatkan mutu kinerja guru dalam mengembangkan keprofesian melalui tindakan reflektif adalah sebagai berikut : (1) Mengikuti diklat, seminar, maupun workshop baik yang diselenggarakan sekolah maupun instansi-instansi tertentu serta mengikuti kegiatan rutin MGMP matematika tingkat SMA: (2) Melakukan tindakan kelas. Dengan melakukan tindakan kelas, guru dapat memperbaiki kualitas pembelajaran. Selain itu, penelitian kelas juga merupakan salah satu syarat dari regulasi kenaikan pangkat guru. Namun Guru matematika di sekolah ini kurang optimal dalam melakukan penelitian tindakan kelas sesuai dengan disiplin ilmunya.(3)Pemanfaatan teknologi dan informasi yaitu internet. Guru dapat mencari informasi terkini yang menunjang kinerja guru melalui teknologi informasi yang dimiliki, guru dapat mencari dan menelusuri bahan pustaka, metode mengajar, serta mengakses berbagai informasi lainnya dibutuhkan oleh masing-masing guru.

Menurut Casmudi \& Alipatan ( 2019: 87) mengatakan bahwa mengembangkan kegiatan secara berkelanjutan bagi guru mendorong untuk memelihara, meningkatkan dan memperluas pengetahuan dan keterampilan serta membangun kualitas pribadi yang dibutuhkan dalam kehidupan profesionalnya.

\section{KESIMPULAN}

Berdasarkan hasil data temuan maka penulis menyimpulkan bahwa upaya guru matematika di SMA Negeri 8 dalam meningkatkan mutu kinerja sebagai 
pendidik antara lain: upaya guru dalam mengembangkan kurikulum diantaranya adalah guru menyusun silabus sesuai dengan kurikulum yang mengacu pada kurikulum . RPP dikembangkan guru menyesuaikan dengan apa yang dinyatakan dalam silabus, dengan kondisi di satuan pendidikan yang mencakup mata pelajaran, materi pokok, alokasi waktu, selanjutnya merancang RPP sesuai dengan standar isi, tujuan pembelajaran, metode pembelajaran, media dan alat sumber belajar, langkah-langkah kegiatan pembelajaran dan penilaian yang dibuat secara mandiri maupun dibuat bersama dalam forum MGMP matematika.

Selain itu, upaya guru dalam meningkatkan mutu kinerja sebagai pendidik dalam memberi penilaian dan evaluasi adalah sebagai berikut dengan menyusun alat penilaian yang sesuai dengan tujuan pembelajaran dengan berbagai jenis penilaian seperti yang tertulis dalam RPP dan Guru memanfaatkan hasil penilaian sebagai bahan penyusunan rancangan pembelajaran dilakukan selanjutnya . Namun terkadang guru tidak menganalisis hasil penilaian untuk mengidentifikasi topik/kompetensi dasar yang sulit.

Selanjutnya, upaya guru matematika dalam meningkatkan kinerja guru yakni dengan memperlakukan semua peserta didik secara adil, menjaga hubungan baik dan peduli dengan teman sejawat serta sering berinteraksi dengan peserta didik dan tidak membatasi perhatiannya hanya pada kelompok tertentu.

Selain itu, upaya guru dalam meningkatkan mutu kinerja guru sebagai tenaga pendidik dalam menunjukkan pribadi yang dewasa dan teladan yaitu dengan bertingkah laku sopan dalam berbicara, berpenampilan dan berbuat baik terhadap semua peserta didik, orang tua, dan teman sejawat serta bersikap dewasa dalam menerima masukan dari peserta didik dan memberi kesempatan kepada peserta didik dan memberikan kesempatan kepada peserta didik untuk berpartisipasi dalam proses pembelajaran

Selanjutnya, Upaya guru dalam meningkatkan mutu kinerja guru dalam mengembangkan keprofesian adalah mengikuti diklat, seminar, maupun workshop baik yang diselenggarakan sekolah maupun instansi-instansi tertentu serta mengikuti kegiatan rutin MGMP matematika tingkat SMA. Selain itu, melakukan tindakan kelas. Dengan melakukan tindakan kelas, guru dapat memperbaiki kualitas pembelajaran. Selain itu, penelitian kelas juga merupakan salah satu syarat dari regulasi kenaikan pangkat guru. Namun Guru matematika di sekolah ini kurang optimal dalam melakukan penelitian tindakan kelas sesuai dengan disiplin ilmunya. Serta pemanfaatan teknologi dan informasi yaitu internet. Guru dapat mencari informasi terkini yang menunjang kinerja guru melalui teknologi informasi yang dimiliki, guru dapat mencari dan menelusuri bahan pustaka, metode mengajar, serta mengakses berbagai informasi lainnya dibutuhkan oleh masing-masing guru.

\section{DAFTAR PUSTAKA}

Casmudi, \& Alipatan, M. (2019). Pengembangan Kompetensi Guru. Bandung: Mujahid Press.

Hamzah, A. (2019). Metode Penelitian

Kualitatif: Rekontruksi Pemikiran

Dasar Serta Contoh Penerapan

Pada Ilmu Pendidikan, Sosial Dan

Humaniora. Batu: Literasi

Nusantara.

Moh, R., \& Nurfuadi. (2009). Kepribadian

Guru , Upaya mengembangkan kepribadian guru yag sehat dimasa depan. Yogyakarta: Grafindolitera Media.

Mulyasa, E. (2013). Standar Kompetensi dan Sertifikasi Guru. Bandung: PT Remaja Rosdakarya.

Peraturan Pemerintah Nomor 16 tahun 2007 tentang Standar Kualifikasi Akademik Dan Kompetensi Guru. 
Peraturan Pemerintah Nomor 32 Tahun 2013 Tentang Perubahan atas Peraturan Pemerintah Nomor 19 Tahun 2005 Tentang Standar Nasional Pendidikan.

Peraturan Menteri Negara Pendayagunaan Aparatur Negara dan Reformasi Birokrasi Nomor 16 Tahun 2009 tentang Jabatan Fungsional Guru Dan Angka Kreditnya.

Sukmadinata. (2015). Metode Penelitian Pendidikan. Bandung: PT. Remaja Rosdakarya.

Sumardi, (2016). Pengembangan Guru Profesionalisme Guru MGMP Berbasis Model dan Implimentasi untuk Meningkatkan Kinerja Guru. Yogyakarta :CV Budi Utama

Undang-Undang Republik Indonesia Nomor 14 Tahun 2005 edisi 2009, Tentang Guru dan Dosen, Bandung, Depdiknas, Citra Umbara.

Undang-Undang nomor 20 tahun 2003 tentang Sistem Pendidikan Nasional 